NOTE

\title{
Sequence analysis of the internal transcribed spacer (ITS) region reveals a novel clade of Ichthyophonus sp. from rainbow trout
}

\author{
C. Rasmussen ${ }^{1}$, M. K. Purcell ${ }^{1}$, J. L. Gregg ${ }^{2}$, S. E. LaPatra ${ }^{3}$, J. R. Winton ${ }^{1}$, \\ P. K. Hershberger ${ }^{2, *}$ \\ ${ }^{1}$ Western Fisheries Research Center, US Geological Survey, 6505 NE 65th Street, Seattle, Washington 98115, USA \\ ${ }^{2}$ Western Fisheries Research Center, US Geological Survey, Marrowstone Marine Field Station, \\ 616 Marrowstone Point Road, Nordland, Washington 98358, USA \\ ${ }^{3}$ Research Division, Clear Springs Foods, Inc., PO Box 712, Buhl, Idaho 83316, USA
}

\begin{abstract}
The mesomycetozoean parasite Ichthyophonus hoferi is most commonly associated with marine fish hosts but also occurs in some components of the freshwater rainbow trout Oncorhynchus mykiss aquaculture industry in Idaho, USA. It is not certain how the parasite was introduced into rainbow trout culture, but it might have been associated with the historical practice of feeding raw, ground common carp Cyprinus carpio that were caught by commercial fisherman. Here, we report a major genetic division between west coast freshwater and marine isolates of Ichthyophonus hoferi. Sequence differences were not detected in 2 regions of the highly conserved small subunit (18S) rDNA gene; however, nucleotide variation was seen in internal transcribed spacer loci (ITS1 and ITS2), both within and among the isolates. Intra-isolate variation ranged from 2.4 to 7.6 nucleotides over a region consisting of $\sim 740 \mathrm{bp}$. Majority consensus sequences from marine/anadromous hosts differed in only 0 to 3 nucleotides (99.6 to $100 \%$ nucleotide identity), while those derived from freshwater rainbow trout had no nucleotide substitutions relative to each other. However, the consensus sequences between isolates from freshwater rainbow trout and those from marine/anadromous hosts differed in 13 to 16 nucleotides (97.8 to $98.2 \%$ nucleotide identity).
\end{abstract}

KEY WORDS: Ichthyophonus hoferi $\cdot$ Rainbow trout $\cdot$ Ribosomal gene complex $\cdot$ ITS1 $\cdot$ ITS2

\section{INTRODUCTION}

Taxonomic uncertainties have accompanied the identification of Ichthyophonus hoferi since its original description by B. von Hofer in 1893 (reviewed by McVicar 1999). More recently, sequence analysis of the small subunit (SSU, also termed 18S) region of the ribosomal RNA gene complex (rDNA) confirmed that Ichthyophonus belongs to a primitive protistan group that is related to the common ancestor of animals and fungi (Wainright et al. 1993). This novel group initially consisted of Dermocystidium, the rosette agent, Ichthyophonus and Psorospermium, giving rise to the acronym 'DRIP clade' (Ragan et al. 1996) that was later reorganized into the newly created class Mesomycetozoea (Herr et al. 1999).

A lack of distinguishing characteristics in the original species description (von Hofer 1893), combined with a high degree of morphological plasticity in life history stages (Okamoto et al. 1985), likely resulted in the grouping of several closely related organisms into a species assemblage that is collectively referred to as Ichthyophonus hoferi (Alderman 1982, Spanggaard et al. 1996). Phylogenetic studies using 18S rDNA sequences of $I$. hoferi have revealed only 5 SSU rDNA haplotypes worldwide (Criscione et al. 2002). In the NE 
Pacific, 2 SSU haplotypes that share $99.5 \%$ nucleotide similarity have been reported, with sequences from coastal rockfishes Sebastes spp. differing from those of sympatric Pacific herring Clupea pallasii, Chinook salmon Oncorhynchus tshawytscha (Criscione et al. 2002) and Puget Sound rockfish Sebastes emphaeus (Halos et al. 2005). Additionally, a phenotypic difference in salinity tolerance has been reported among $I$. hoferi isolates from freshwater rainbow trout $O$. mykiss and marine fish, although they share $100 \%$ SSU rDNA nucleotide identity (Hershberger et al. 2008). To avoid the confusion surrounding the I. hoferi species complex in this paper, the organism will hereafter be referred to generically as Ichthyophonus.

The rDNA complex of eukaryotes consists of a tandem set of genes and spacers, including the 18S rRNA, an internal transcribed spacer 1 (ITS1), the 5.8S rRNA, a second internal transcribed spacer (ITS2), the 28S rRNA, and a second external transcribed spacer (ETS2) (Cooper 2000). The goal of this study was to use the rDNA sequences of the less conserved ITS1 and ITS2 regions to assess potential genetic differences among Ichthyophonus isolates that were derived from a range of marine, anadromous and freshwater fish species in the NE Pacific. The isolates that were used included representatives of the most common SSU rDNA sequence types that were observed in the NE Pacific (Criscione et al. 2002, Halos et al. 2005, Hershberger et al. 2008).

\section{MATERIALS AND METHODS}

Ichthyophonus isolates. Ichthyophonus was isolated and cultivated from heart tissue explants of 4 host species (Table 1) as previously described (Hershberger et al. 2008). Briefly, heart tissue was aseptically removed and placed in an isolation medium consisting of Eagle's MEM supplemented with foetal bovine serum (5\% v/v), penicillin $\left(100 \mathrm{IU} \mathrm{ml}^{-1}\right)$, streptomycin $\left(100 \mu \mathrm{g} \mathrm{ml}^{-1}\right)$ and gentamycin $\left(100 \mathrm{\mu g} \mathrm{ml}^{-1}\right)$, and buffered to $\mathrm{pH} 7.8$ with $1 \mathrm{M}$ Tris (MEM, pH 7.8). Cultures were incubated at $15^{\circ} \mathrm{C}$ for $\sim 14 \mathrm{~d}$, after which excess host tissue was removed. To generate sufficient quantities of Ichthyophonus for nucleic acid extraction, parasite growth was stimulated by passing the isolates into a hyphenation medium consisting of MEM that was adjusted to $\mathrm{pH} 3.5$ and supplemented with $1 \%$ glucose (Spanggaard et al. 1994). Resporulation was then stimulated by returning the isolates to $\mathrm{pH} 7.8$ for several days before genomic DNA was isolated. The rainbow trout RBT2 sample (Table 1) was not cultured prior to molecular analysis.

Isolation of genomic DNA. Genomic DNA was isolated from cultured Ichthyophonus or from infected heart tissue using a DNeasy blood and tissue kit (Qiagen) following the manufacturer's recommendations

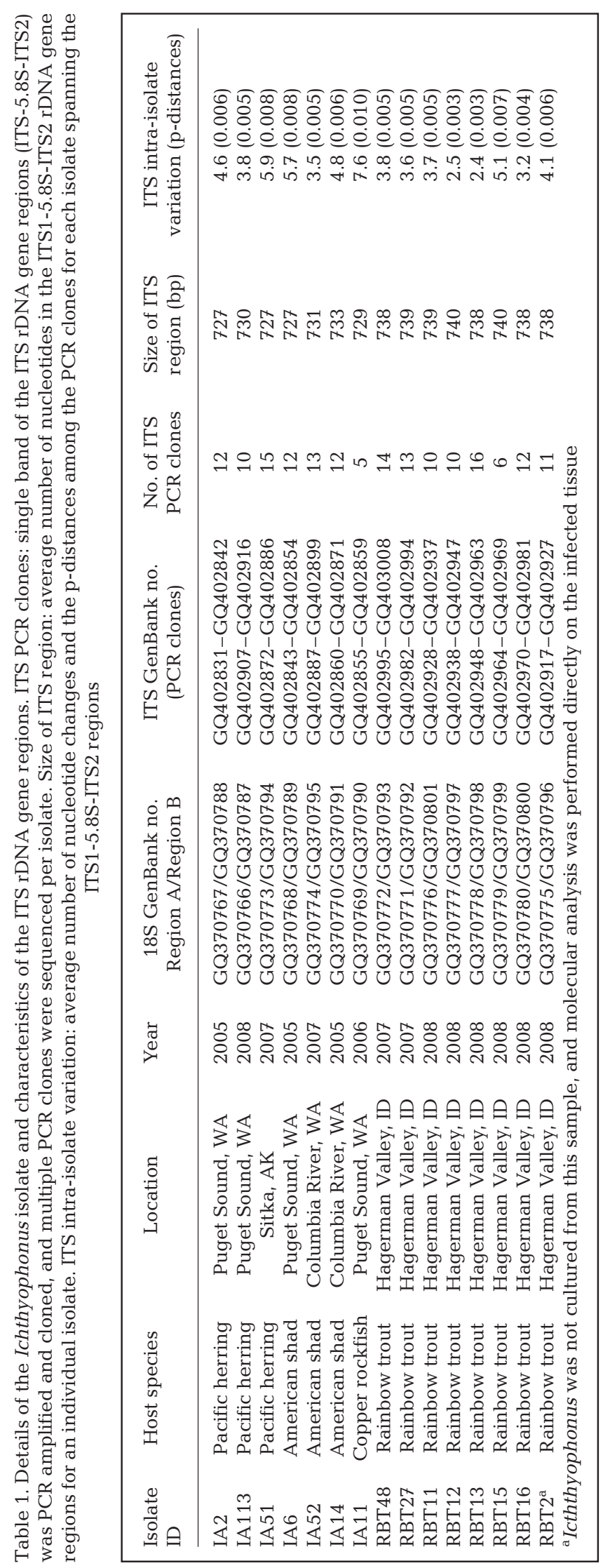


for tissue extraction, with several modifications. Ichthyophonus spores or hyphae were initially placed in a tube containing beads (lysing matrix D; Bio 101) and incubated with $360 \mu \mathrm{l}$ of tissue lysis buffer and $40 \mu \mathrm{l}$ of proteinase $\mathrm{K}$ (Qiagen) at $55^{\circ} \mathrm{C}$ for $2 \mathrm{~h}$ before being homogenized in the Fast Prep FP120 instrument (Bio 101) for $40 \mathrm{~s}$. The samples were centrifuged at $7200 \times g$ for $1 \mathrm{~min}$, an additional $40 \mu \mathrm{l}$ of proteinase $\mathrm{K}$ was added, and the homogenates were incubated overnight at $55^{\circ} \mathrm{C}$. The Ichthyophonus homogenates were then subjected to a second round of bead homogenization, and the samples were extracted with no further modifications to the manufacturer's protocol.

PCR amplification, cloning, and sequencing of SSU (18S) and ITS (ITS1-5.8S-ITS2) rDNA regions. PCR amplification and sequencing of 2 segments (A and B) of the SSU rDNA were performed as previously described (Criscione et al. 2002, Halos et al. 2005). Briefly, region A primers amplify a 640 bp segment, while region B primers amplify a 673 bp segment. Segments were direct sequenced in the forward and reverse directions using the ABI Big Dye Terminator v1.1 and an ABI 3700 automated sequencer (Applied Biosystems).

The region spanning ITS1, 5.8S and ITS2 was amplified using the following primers: 5'-GTT TCC GTA GGT GAA CCT GC-3' and 5'-TCC TCC GCT TAT TRA TAT GC-3'. DNA amplification was achieved using the GoTaq PCR enzyme and buffer system (Promega) with 1 cycle of $95^{\circ} \mathrm{C}$ for 5 min, followed by 35 cycles of $94^{\circ} \mathrm{C}$ for $45 \mathrm{~s}, 62^{\circ} \mathrm{C}$ for $45 \mathrm{~s}$, and $72^{\circ} \mathrm{C}$ for $1.5 \mathrm{~min}$. PCR products were cloned using the pGEM-T easy vector system (Promega) or Topo-TA cloning kit for sequencing (Invitrogen), to assess intra-isolate sequence variation. Clone insert sizes were assessed by PCR amplification using vector primers. Multiple clones of PCR products from each isolate containing inserts of expected size were sequenced using the high-throughput genomic unit at the University of Washington (Seattle, WA, USA). A total of 5 to 16 clones were sequenced per isolate (Table 1).

Sequence and phylogenetic analyses. Sequence chromatograms were visually assessed and edited using the Sequencher v4.5 software (Gene Codes). Phylogenetic comparisons were performed after the sequences had been aligned using ClustalX (Thompson et al. 1997), with default parameter settings including the pairwise and multiple alignment gap-opening/extension penalties of $10 / 0.10$ and $3 / 1.8$, respectively. Phylogenetic analyses were performed using either the majority consensus sequences for each isolate (derived from all PCR clones for each isolate) or all individual PCR clone sequences. Alignments were examined by eye and no adjustments were deemed necessary. The ITS1-5.8S-ITS2 sequence from a related mesomycetozoean, Amoebidium parasiticum (AY388646), was used as an outgroup species. Phylogenetic inferences were made using the neighbor-joining and maximum parsimony methods in the MEGA v4.0 software package (Tamura et al. 2007). Tree topologies were validated by bootstrapping 1000×.

\section{RESULTS}

All isolates that were used in this study were identical across the $A$ and $B$ regions of the SSU rDNA (Table 1), and the sequences were identical to those of Ichthyophonus hoferi (e.g. AF467798 and AF467797).

Primers that were designed to amplify the ITS1-5.8SITS2 region of Ichthyophonus hoferi produced an amplicon of $\sim 740 \mathrm{bp}$. Sequencing of multiple clones for each isolate showed that intra-isolate variation ranged from 2.4 to 7.6 nucleotides in the region examined ( $p$ distances range: 0.003 to 0.010 ) (Table 1). The isolate from copper rockfish Sebastes caurinus (IA11) had the highest level of intra-specific variation (7.6 changes out of 729 nucleotides). Majority consensus sequences were derived from all the clones for each isolate. Consensus sequences from the 6 isolates from herring or shad had no nucleotide substitutions relative to each other, and those from the 8 isolates from trout had no nucleotide substitutions relative to each other. The majority consensus sequence from the single rockfish isolate differed from those of herring/shad isolates by 3 nucleotides and from those of trout isolates by 16 nucleotides (Table 2). The consensus sequences from herring/shad differed from those of trout by 13 nucleotides.

The ITS2 region had the greatest mean number of nucleotide differences (8.7 changes out of 311 nucle-

Table 2. Pairwise differences among representative Ichthyophonus isolates for the ITS rDNA regions (ITS1-5.8S-ITS2). The $\mathrm{p}$-distance is shown above the diagonal, while the number of nucleotide differences (out of 637 aligned nucleotides) is shown below the diagonal. IA2 (herring) is shown as the representative for IA2, IA113 (herring), IA51 (herring), IA6 (shad), IA52 (shad), and IA14 (shad), whose majority consensus sequences had no nucleotide substitutions relative to each other. RBT2 is shown as the representative for all isolates from rainbow trout (RBT2, RBT48, RBT27, RBT11, RBT12, RBT13, RBT15, and RBT16), whose majority sequences had no nucleotide sequences relative to each other

\begin{tabular}{|lcccc|}
\hline & $\begin{array}{c}\text { IA2 } \\
\text { (herring) }\end{array}$ & $\begin{array}{c}\text { IA11 } \\
\text { (rockfish) }\end{array}$ & $\begin{array}{c}\text { RBT2 } \\
\text { (trout) }\end{array}$ & $\begin{array}{c}\text { Amoebidium } \\
\text { parasiticum }\end{array}$ \\
\hline IA2 (herring) & - & 0.005 & 0.020 & 0.190 \\
IA11 (rockfish) & 3 & - & 0.025 & 0.190 \\
RBT2 (trout) & 13 & 16 & - & 0.193 \\
A. parasiticum & 121 & 119 & 123 & - \\
\hline
\end{tabular}


otides) among the consensus sequences from herring (represented by IA2), rockfish (IA11) and rainbow trout (represented by RBT2). The ITS1 region also varied among these 3 representative isolates $(2.7$ changes out of 230 nucleotides). The rainbow trout 5.8S rDNA sequence had a single nucleotide change (out of 109 nucleotides) relative to the herring/rockfish consensus sequences.

Phylogenetic analysis using the entire ITS region consensus sequence for each isolate (Table 1) supports a genetic division between freshwater and marine isolates of Ichthyophonus. Neighbor-joining and maximum parsimony analyses gave similar topologies (Fig. 1). All isolates that were derived from either marine or anadromous host species clustered to the exclusion of isolates from freshwater rainbow trout. Phylogenetic analysis using all PCR clone sequences, rather than the consensus sequences, gave a similar topology (data not shown).

\section{DISCUSSION}

We demonstrate that genetic variation in the ITS regions can be informative in distinguishing among isolates of Ichthyophonus that have $100 \%$ sequence identity in the more highly conserved SSU rDNA region, and that phylogenetic analysis of these ITS sequences supports the presence of a major division between Ichthyophonus isolates from rainbow trout in Idaho and those from marine and anadromous hosts in the NE Pacific (Fig. 1). The genetic difference between the 2 clades appears to mirror phenotypic differences between representative isolates that include differences in stability in freshwater and seawater (Hershberger et al. 2008). Because rDNA regions exist as multi-copy genes, we expected some level of sequence variation among clones that were generated from individual isolates. However, the Ichthyophonus isolates that were used in this study did not originate from single cell cultures; thus, we cannot exclude the possibility that some of the sequence variation among the clones of a given isolate was due to genetic differences between individual cells within that isolate. Nevertheless, the level of ITS sequence variation between marine and freshwater clades was substantially greater than that among clones from individual cultures (Table 1).

Ichthyophonus is generally considered to be a pathogen of wild, marine fish (McVicar 1999), and reports in fish from the eastern North Pacific began surfacing in the late 1970s and early 1980s (reviewed by Hershberger et al. 2002). The pathogen is currently ubiquitous in many marine hosts throughout the NE Pacific, where it has been implicated as a populationlimiting factor (Marty et al. 1998, Hershberger et al. 2002). Ichthyophonus was first reported in freshwater rainbow trout from intensive culture facilities in Washington State during an epizootic in 1952 (Rucker \& Gustafson 1953). Early epizootics in Idaho trout culture were linked to the practice of feeding raw tissues from common carp Cyprinus carpio (Erickson 1965). Epizootics due to Ichthyophonus ceased when this practice was stopped, and there were no reports of the parasite for $\sim 40$ yr. It is not clear whether Ichthyophonus remained endemic in the trout industry or if the con-

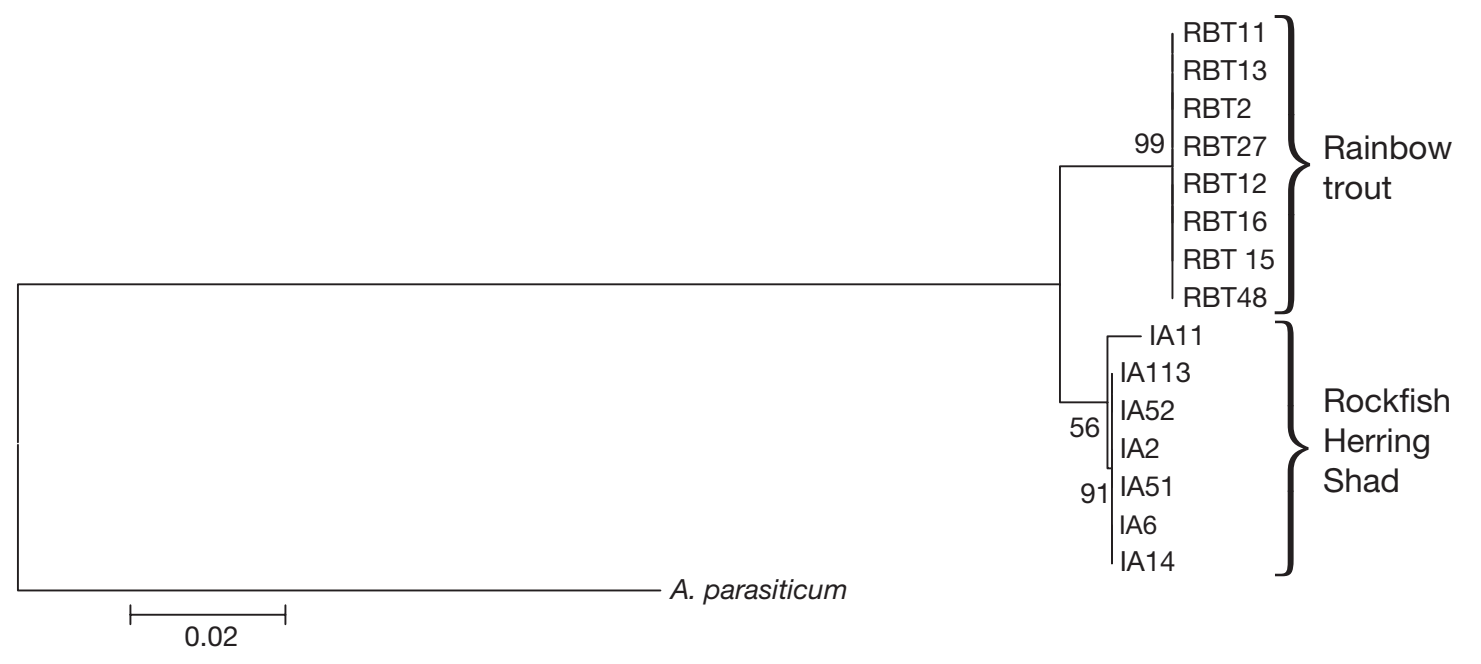

Fig. 1. Evolutionary relationships of Ichthyophonus isolates based on the majority consensus sequence of the ITS region (ITS1-5.8S-ITS2) as inferred using the neighbour-joining method (1000 bootstrap iterations). A similar tree topology was obtained using the maximum parsimony method (not shown). Isolates are derived from rainbow trout (RBT-11, 13, 2, 27, 12 16, 15 and 48), Pacific herring (IA2, IA113 and IA51), American shad (IA6, IA52 and IA14), and copper rockfish (IA11). Amoebidium parasiticum (AY388646) was used as an outgroup 
temporary isolates represent a new introduction. Typing of contemporary and historical archived samples from a larger host and geographical range will be needed to determine if the unique ITS lineage that is identified in rainbow trout reflects (1) divergence from the common Pacific northwest marine type within the aquaculture setting, (2) a unique parasite source (e.g. North American carp), or (3) both.

It is unlikely that a single species occupies the broad host and geographical ranges reported for Ichthyophonus hoferi that include a near-circum polardistribution in more than 80 host species, including freshwater and marine elasmobranch and teleost fish, amphibians, reptiles, and fish-eating birds (reviewed by McVicar 1999). Morphological (Rand 1994) and SSU rDNA sequence differences in I. hoferi isolates from fish in the Atlantic Ocean provided initial evidence for speciation within the genus (Rand et al. 2000), and it is likely that additional variation will be found on a larger biogeographical scale. In addition to identifying genetic separation between freshwater and marine isolates of Ichthyophonus in the Pacific northwest, preliminary evaluations of the ITS regions also indicate genetic separation between marine isolates in the Atlantic and Pacific Oceans (P. K. Hershberger \& M. K. Purcell unpubl. data). In the future, sequence analysis of ITS or other informative regions of the Ichthyophonus genome may assist in the understanding of phenotypic and epidemiological differences among isolates (e.g. host-specific virulence, route of infection, mechanisms of transmission and features of the life cycle), including the identification of alternate hosts.

Acknowledgements. We thank C. Grady and J. C. Woodson from the Western Fisheries Research Center, and B. Shewmaker, M. Gonzales and R. Burkhart from Clear Springs Foods, Inc. for technical assistance. Funding was provided by the Exxon Valdez Oil Spill Trustee Council, Project \# 070819, and the US Geological Survey Fisheries and Aquatic Resources Program. The use of trade, firm, or corporation names in this publication is for the information and convenience of the reader. Such use does not constitute an official endorsement or approval by the US Department of Interior or the US Geological Survey of any product or service to the exclusion of others that may be suitable.

\section{LITERATURE CITED}

Alderman DJ (1982) Fungal diseases of aquatic animals. In: Roberts RJ (ed) Microbial diseases of fish. Academic Press, London, p 189-242

Cooper GM (2000) The cell, a molecular approach, Vol 2. Sinauer Associates, Washington, DC

> Criscione CD, Watral V, Whipps CM, Blouin MS, Jones SRM, Kent ML (2002) Ribosomal DNA sequences indicate isolated populations of Ichthyophonus hoferi in geographic sympatry in the north-eastern Pacific Ocean. J Fish Dis 25: $575-582$

Erickson JD (1965) Report on the problem of Ichthyosporidium in rainbow trout. Prog Fish-Cult 27:179-184

- Halos D, Hart SA, Hershberger PK, Kocan RM (2005) Ichthyophonus in Puget Sound rockfish from the San Juan Islands Archipelago and Puget Sound, Washington, USA. J Aquat Anim Health 17:222-227

> Herr RA, Ajello L, Taylor JW, Arseculeratne SN, Mendoza L (1999) Phylogenetic analysis of Rhinosporidium seeberi's 18S small-subunit ribsomal DNA groups this pathogen among members of the protoctistan Mesomycetozoa clade. J Clin Microbiol 37:2750-2754

> Hershberger PK, Stick K, Bui B, Carroll C and others (2002) Incidence of Ichthyophonus hoferi in Puget Sound fishes and its increase with age of Pacific herring. J Aquat Anim Health 14:50-56

Hershberger PK, Pacheco CA, Gregg JL, Purcell MK, LaPatra SE (2008) Differential survival of Ichthyophonus isolates indicates parasite adaptation to its host environment. J Parasitol 94:1055-1059

Marty GD, Freiberg EF, Meyers TR, Wilcock J, Farver TB, Hinton DE (1998) Viral hemorrhagic septicemia virus, Ichthyophonus hoferi, and other causes of morbidity in Pacific herring Clupea pallasi spawning in Prince William Sound, Alaska, USA. Dis Aquat Org 32:15-40

McVicar AH (1999) Ichthyophonus and related organisms. In: Woo PTK, Bruno DW (eds) Fish diseases and disorders, Vol 3. Viral, bacterial, and fungal infections. CABI Publishing, New York, p 661-687

Okamoto N, Nakase K, Suzuki H, Nakai Y, Fujii K, Sano T (1985) Life history and morphology of Ichthyophonus hoferi in vitro. Fish Pathol 20:272-285

> Ragan MA, Louise Goggins C, Cawthorn RJ, Cerenius L and others (1996) A novel clade of protistan parasites near the animal-fungal divergence. Proc Natl Acad Sci USA 93: 11907-11912

> Rand TG (1994) An unusual form of Ichthyophonus hoferi (Ichthyophonales: Ichthyophonaceae) from yellowtail flounder Limanda ferruginea from the Nova Scotia shelf. Dis Aquat Org 18:21-28

Rand TG, White K, Cannone JJ, Gutell RR, Murphy CA, Ragan MA (2000) Ichthyophonus irregularis sp. nov. from the yellowtail flounder Limanda ferruginea from the Nova Scotia shelf. Dis Aquat Org 41:31-36

> Rucker RR, Gustafson PV (1953) An epizootic among rainbow trout. Prog Fish-Cult 15:179-181

> Spanggaard B, Gram L, Okamoto N, Huss HH (1994) Growth of the fish-pathogenic fungus, Ichthyophonus hoferi, measured by conductimetry and microscopy. J Fish Dis 17:145-153

Spanggaard B, Skouboe P, Rossen L, Taylor JW (1996) Phylogenetic relationships of the intercellular fish pathogen Ichthyophonus hoferi and fungi, choanoflagellates, and the rosette agent. Mar Biol 126:109-115

> Tamura K, Dudley J, Nei M, Kumar S (2007) MEGA4: molecular evolutionary genetics analysis (MEGA) software version 4.0. Mol Biol Evol 24:1596-1599

Thompson JD, Gibson TJ, Plewniak F, Jeanmougin F, Higgins DG (1997) The CLUSTAL_X windows interface: flexible strategies for multiple sequence alignment aided by quality analysis tools. Nucleic Acids Res 25:4876-4882

von Hofer B (1893) Eine Salmonidenerkrankung. Allg FischZtg 18:168-171

Wainright PO, Sogin ML, Stickel SK (1993) Monophyletic origins of the Metazoa: an evolutionary link with fungi. Science 260:340-342

Submitted: August 6, 2009; Accepted: November 17, 2009

Proofs received from author(s): February 13, 2010 